\title{
STUDI KELAYAKAN PEMBANGUNAN PEMBANGKIT LISTRIK TENAGA MIKROHIDRO Studi Kasus: PLTMH Minggir pada saluran irigasi Minggir di Padukuhan Klagaran Desa Sendangrejo Kecamatan Minggir Kabupaten Sleman
}

Oleh: Ady Purnama

\begin{abstract}
ABSTRAKSI
Penelitian tentang Perencanaan Pembangkit Listrik Tenaga Mikrohidro Minggir Pada Saluran Irigasi Minggir Di Padukuhan Klagaran, Desa Sendangrejo, Kecamatan Minggir Kabupaten Sleman ini bertujuan untuk mengetahui layak atau tidaknya PLTMH dibangun.

Penelitian ini dilakukan dengan cara menganalisis struktur bangunan air secara teknis dan menganalisis anggaran biaya perencanaan dengan analisis ekonomi. Pengumpulan data dilakukan dengan cara mengambil langsung dari dinas terkait dan pengukuran langsung di lapangan.

Hasil penelitian menunjukkan bahwa potensi daya yang dibangkitkan dari PLTMH Minggir adalah sebesar 23,54 kilowatt. Pembangunan PLTMH ini memenuhi kriteria kelayakan secara teknis, sedangkan secara finansial pembangunan ini tidak dapat mendatangkan keuntungan jika dibiayai dengan pinjaman bank dengan bunga $18 \%$ per tahun. Akan tetapi, keuntungan akan diperoleh jika dibiayai dengan pinjaman tanpa bunga atau hibah dari pemerintah ataupun dari pihak donor.
\end{abstract}

Kata Kunci : Kelayakan, Analisis Teknis, Analisis Ekonomis, PLTMH Minggir.

\section{PENDAHULUAN}

Pembangkit Listrik Tenaga Mikrohidro (PLTMH) adalah salah satu pembangkit listrik low head dengan kapasitas kurang dari 1 Mega Watt (MW). PLTMH dipilih sebagai salah satu energi alternatif dikarenakan memiliki beberapa keunggulan dibanding dengan pembangkit listrik jenis lainnya, seperti bersih lingkungan, renewable energy, tidak konsumtif 
terhadap pemakaian air, lebih awet (tahan lama), biaya operasinya lebih kecil dan sesuai untuk daerah terpencil. Disamping itu perawatan mekanik dan elektrik PLTMH lebih mudah.

PLTMH Minggir merupakan salah satu pemanfaatan mikrohidro yang terletak di Dusun Klagaran Sendangrejo Minggir Sleman Yogyakarta yang dilakukan oleh Pemerintah Kabupaten Sleman. Lokasi PLTMH Minggir dapat dilihat pada Gambar dibawah.

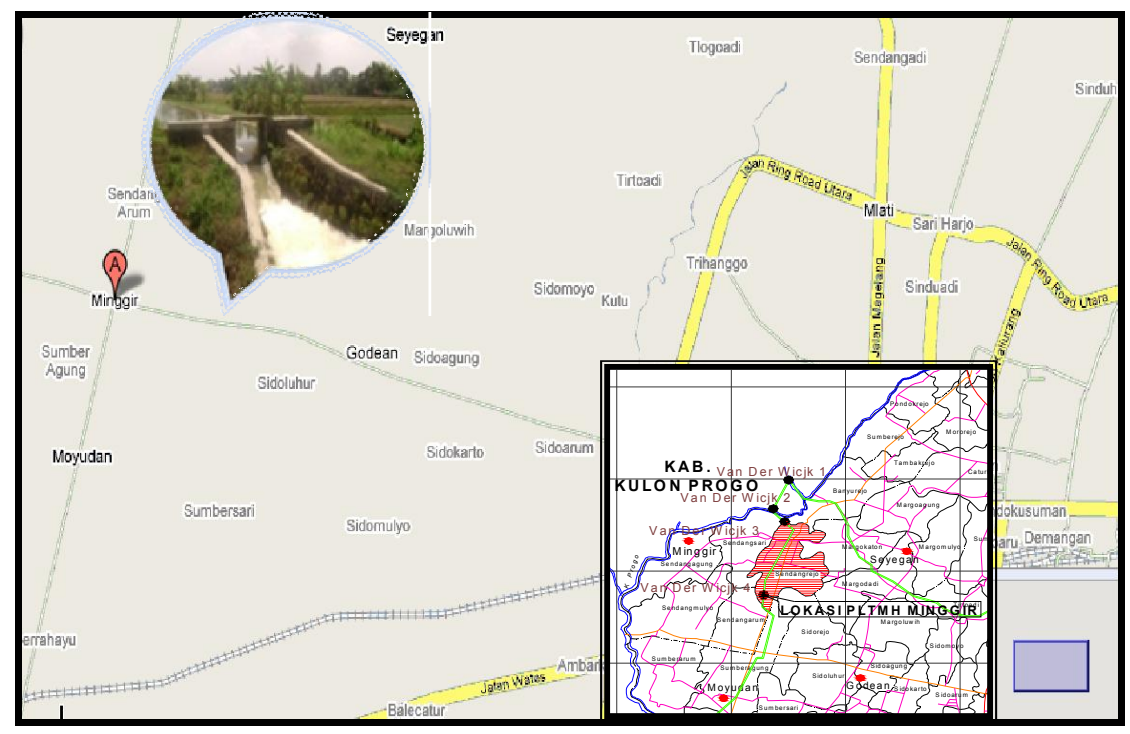

Lokasi rencana PLTMH Minggir

Perencanaan PLTMH Minggir telah dilakukan pada tahun 2008 oleh Dinas Pengairan Pertambangan dan Penanggulangan Bencana Alam (P3BA) Kabupaten Sleman dengan menugaskan konsultan CV. Bangun Cipta Persada. Namaun dari perencanaan tersebut, belum pernah dilakukan studi kelayakan. Karena itu, penelitian ini mengkaji rencana pembangunan PLTMH Minggir dalam hal kelayakannya. Semua data teknis perencanaan mengacu pada 
perencanaan konsultan CV.Bangun Cipta Persada. Kelayakan PLTMH Minggir ditinjau pada aspek teknis dan ekonomi.

Studi kelayakan perencanaan pembangkit listrik tenaga mikrohidro di Dusun Klagaran Desa Sendangrejo Kecamatan Minggir Kabupaten Sleman ini dimaksudkan untuk menganalisis kelayakannya dari sisi teknis dan ekonomi. Sedangkan tujuan yang ingin dicapai adalah agar dapat diketahui kelayakan dari rencana pembangunan PLTMH ini.

Kegiatan yang dilakukan dalam studi kelayakan PLTMH Minggir mencakup: (1) Pengumpulan data, terdiri dari: Data debit, gambar rencana, daya yang dibangkitkan, RAB diperoleh dari CV. Bangun Cipta Persada, dan Data mekanikal dan elektrikal diperoleh dari CV. Cihanjuang Inti Teknik Bandung; (2) Analisis Teknis, terdiri dari: Analisis struktur bangunan air, Analisis struktur menggunakan program SAP2000 version 11.0.0, dan Perhitungan kapasitas struktur; dan (3) Analisis Ekonomi: Sumber dana berasal dari pinjaman bank, Sumber dana berasal dari pemerintah atau donor, dan Sumber dana hibah dari pemerintah atau donor.

Menurut GTZ, biaya investasi awal untuk sebuah pembangkit listrik tenaga air berkisar antara US\$ 1500 per kW sampai dengan US\$ 7000 per kW, tergantung dari kondisi lapangan, sedangkan biaya pemeliharaan ditetapkan sebesar 3\% dari biaya investasi awal untuk setiap tahunnya (T Meier, 1995).

Di Asia, RRC mempunyai mikrohidro yang paling banyak yaitu \pm 85.000 unit dengan 5\%-nya berkapasitas kurang dari 500 kW. Di negara-negara yang sedang berkembang, pembangunan PLTMH merupakan cara yang tepat untuk memenuhi kebutuhan energi pada daerah terpencil. Untuk desa terpencil di daerah pegunungan, pembangunan PLTMH merupakan salah satu 
solusi atas program pemerintah tersebut, karena dengan letak daerah yang dataran tinggi, instalasi tegangan tinggi dinilai tidak ekonomis (Patty, 1995).

\section{METODE PENELITIAN}

Studi Kelayakan dilakukan dengan tahapan sebagai berikut:

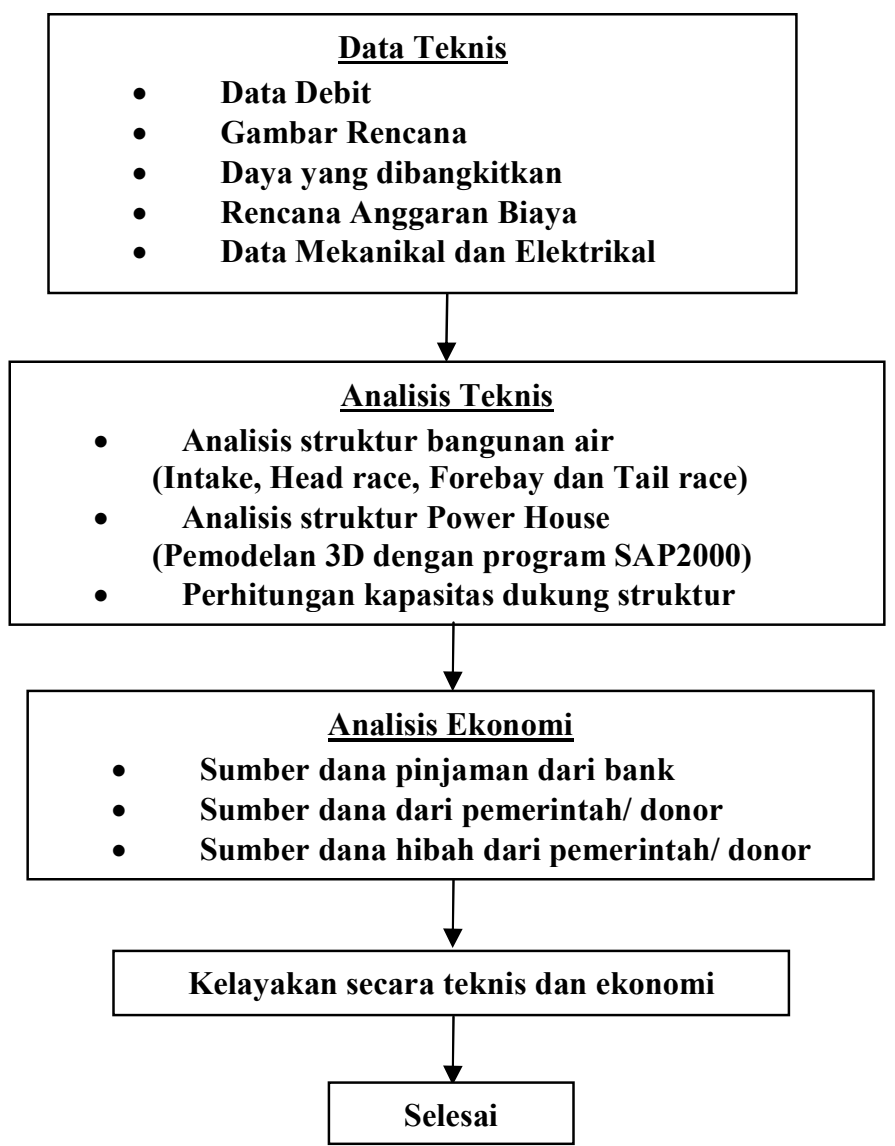

Pengukuran Debit. Salah satu metode pengukuran debit pada saluran terbuka adalah dengan ambang lebar. Ambang lebar yang digunakan pada saluran irigasi Minggir Dusun Klagaran dilengkapi dengan bagian pengendali berbentuk segi empat. Pengukuran debit dilakukan dengan membaca kedalaman air pada hulu saluran dengan bantuan papan duga muka air. 
Hasil pembacaan tinggi muka air pada saluran digunakan untuk menghitung debit air dengan persamaan (1).

$$
\mathrm{Q}=\frac{2}{3} \cdot \mathrm{C}_{\mathrm{d}} \cdot \mathrm{C}_{\mathrm{v}}\left(\frac{2}{3} \mathrm{~g}\right)^{1 / 2} \cdot \mathrm{b} \cdot \mathrm{h}^{3 / 2}
$$

Dengan :
Q : debit saluran $\left(\mathrm{m}^{3} / \mathrm{s}\right)$
$C_{d}:$ koefisien debit
$C_{v}$ : koefisien kecepatan
g : percepatan gravitasi $\left(\mathrm{m}^{2} / \mathrm{s}\right)$
b : lebar mercu (m)
h : kedalaman air di hulu terhadap ambang bangunan ukur (m)

Perhitungan Head. Data head diperoleh dari hasil perhitungan hasil pengukuran topografi. Dari data tersebut didapat elevasi titik saluran atas dan titik elevasi saluran paling bawah sehingga diperoleh nilai beda tinggi (head) saluran yang akan digunakan untuk perhitungan daya yang dapat dibangkitkan.

Rumah Pembangkit. Rumah pembangkit merupakan bangunan yang berfungsi untuk menempatkan alat-alat mekanikal dan alat-alat elektrikal. Bangunan ini digunakan juga sebagai tempat untuk mengontrol operasional PLTMH. Pintu rumah pembangkit dibuat sedemikian rupa sehingga mudah untuk memasukkan alat-alat mekanikal yang ukurannya cukup besar. Perancangan rumah pembangkit harus sesuai dengan standar perencanaan untuk struktur bangunan gedung agar bangunan kuat dalam memikul beban dan gaya yang berada di atasnya. Contoh rumah pembangkit dapat dilihat pada Gambar berikut ini. 


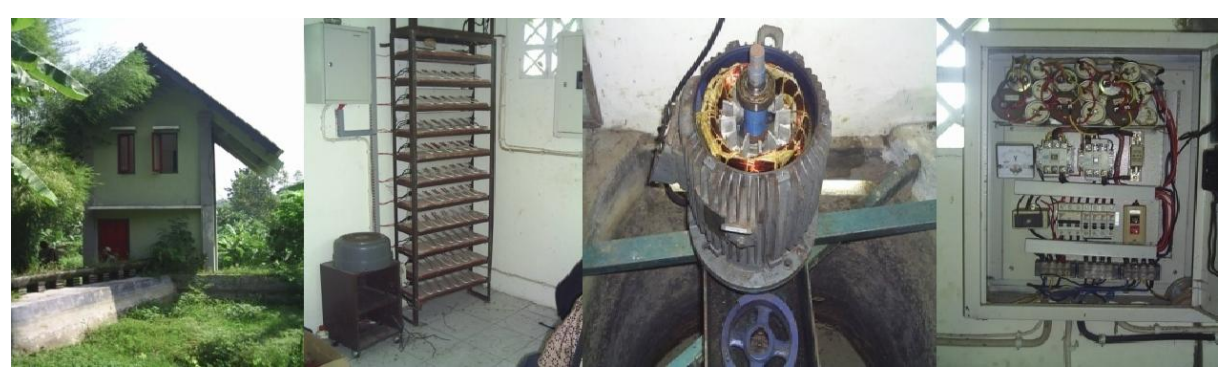

Rumah Pembangkit PLTMH Sewon

Saluran Pengambilan dan Pembuangan. Untuk membangun PLTMH diperlukan saluran pengambilan untuk mengambil air dari saluan irigasi ataupun saluran lainnya menuju rumah pembangkit. Saluran dirancang sesuai dengan debit rencana yang telah ditetapkan. Setelah masuk ke rumah pembangkit dan memutar turbin, air akan ditangkap oleh saluran pembuang untuk dialirkan kembali menuju saluran irigasi ataupun saluran lainnya. Saluran pembuang juga dirancang berdasarkan debit rencana. Rumus yang digunakan pada rancangan ini adalah referensi dari Hidraulika Sungai (Yulistiyanto, 2001).

Apabila saluran berbentuk segi empat, untuk menghitung dimensi dapat digunakan persamaan:

$$
A=B \cdot y
$$

A: Luas tampang basah, B: Lebar saluran, y: Tinggi air dalam saluran

Keliling basah, yaitu:

$$
P=B+2 y
$$

Dari persamaan (2) dan (3) dapat dicari jari-jari hidraulisnya, yaitu:

$$
R=\frac{A}{P}-\frac{B y}{B+2 \gamma}
$$

Dari persamaan (4) dicari nilai koefisien berdasarkan rumus manning, yaitu:

$$
\mathrm{C}=\frac{1}{\mathrm{~T}} \cdot \mathrm{R}^{1 / 6}
$$


Dari persamaan (5) dapat dicari kemiringan dasar saluran, yaitu:

$$
I=\frac{Q^{2}}{a^{2} \cdot C^{2} \cdot h}
$$

Dari persamaan (6) diperoleh nilai I. Dengan diketahui kemiringan saluran, maka dapat dicari tinggi air dalam saluran dengan subtitusi persamaan Manning ke dalam persamaan debit:

$$
V=\frac{1}{\mathrm{n}} \cdot \mathrm{R}^{2 / 3} \cdot \mathrm{I}^{1 / 2}
$$

$$
\mathrm{Q}=\mathrm{B} \cdot \mathrm{y} \cdot \frac{1}{\mathrm{n}} \cdot\left(\frac{\mathrm{Bv}}{\mathrm{a}+2 \mathrm{y}}\right)^{2 / 3} \cdot \mathrm{I}^{1 / 2}
$$

Dari persamaan (7) akan diperoleh nilai y (tinggi air dalam saluran).

Daya yang Dibangkitkan. Apabila pada suatu daerah terdapat potensi air dengan debit $\mathrm{Q} \mathrm{m}^{3} / \mathrm{s}$ dan jatuh dari ketinggian $\mathrm{H}$ meter, maka energi yang dapat dibangkitkan adalah sebesar:

$$
P=\rho . g . H . Q . \eta
$$

$P:$ daya $(\mathrm{kW}) \quad \rho:$ massa jenis air $\left(\mathrm{kg} / \mathrm{m}^{3}\right) \quad Q: \operatorname{debit}\left(\mathrm{m}^{3} / \mathrm{s}\right)$

$\mathrm{H}$ : tinggi/head $(\mathrm{m}) \quad \mathrm{g}$ : percepatan gravitasi sebesar $9,81\left(\mathrm{~m}^{2} / \mathrm{s}\right)$

$\eta$ : efisiensi turbin sebesar 80 - 90\% (Patty, 1995)

Kelayakan Teknis PLTMH. Dalam studi kelayakan pembangunan PLTMH Minggir ini ada beberapa parameter kelayakan secara teknis antara lain:

1. Ketersedian air pada saluran irigasi atau saluran lainnya.

2. Kemampuan struktur menahan beban yang terjadi.

3. Ketersediaan peralatan mekanikal dan elektrikal di pasaran.

Kelayakan Ekonomi PLTMH. Dalam suatu proyek, perlu diketahui tingkat keuntungan dari investasi yang telah ditanamkan. Usaha untuk mengetahui tingkat keuntungan suatu proyek inilah yang dikenal dengan istilah Analisis Ekonomi. 
Tujuan analisis ekonomi antara lain sebagai berikut:

1. Melakukan penilaian apakah investasi yang dilakukan akan memberikan manfaat ekonomi yang cukup

2. Melakukan justifikasi terhadap biaya yang diperlukan untuk membangun suatu proyek dan kemungkinan pengembalian investasi dalam kaitannya dengan pembayaran kembali pinjaman ke pihak donor,

3. Melakukan identifikasi dampak proyek dalam mengurangi tingkat pengangguran di lokasi proyek,

4. Melakukan identifikasi dampak proyek terhadap penghematan devisa Negara,

5. Melakukan identifikasi dampak proyek terhadap pemerataan pendapatan masyarakat terutama yang berpenghasilan rendah.

Untuk melakukan analisis ekonomi, diperlukan beberapa parameter, meliputi;

\section{Komponen biaya (cost)}

Biaya investasi dapat dibagi menjadi dua jenis, yaitu biaya langsung dan biaya tidak langsung. Biaya langsung merupakan total biaya yang diperlukan untuk pembangunan konstruksi pembangkit listrik tenaga mikrohidro, sedangkan biaya tidak langsung meliputi :

a. Biaya tidak terduga untuk pengeluaran yang belum pasti atau belum dapat diperkirakan sekarang.

b. Biaya engineering mencakup biaya untuk kegiatan survey lapangan, studi kelayakan, jasa konsultan perencana dan biaya pengawasan.

c. Bunga selama konstruksi atau pembangunan.

Jumlah biaya langsung dan tidak langsung merupakan biaya investasi proyek. Selain biaya investasi, dihitung pula biaya tahunan yang 
dikeluarkan selama pembangkit listrik tenaga mikrohidro beroperasi. Biaya tahunan meliputi:

a. Bunga pinjaman sesuai dengan suku bunga yang berlaku.

b. Biaya operasional dan perawatan.

\section{Komponen manfaat (benefit)}

Komponen manfaat yang diperhitungkan adalah hanya manfaat yang timbul dan dapat dinilai dengan uang. Manfaat diperhitungkan dari penjualan daya listrik yang dibangkitkan oleh pembangkit listrik tenaga mikrohidro. Formula yang digunakan adalah referensi dari buku Ekonomi Teknik (Waldiyono, MS, 2008). Manfaat diperhitungkan dengan persamaan sebagai berikut:

$$
B=\text { P.T.S.C }
$$

$B$ : manfaat atau penjualan selama satu tahun $(\mathrm{Rp})$

$P$ : daya yang terbangkitkan (kWh) $\quad T$ : waktu selama satu tahun (jam)

$S$ : harga jual daya listrik (Rp/kWh) $\quad c$ : faktor koreksi (\%)

\section{Arus kas (cast flow)}

Arus kas merupakan suatu informasi keuangan yang merinci proyeksi kas masuk yang berasal dari pendapatan dan kas keluar untuk biaya proyek. Dari arus kas ini dapat diketahui kapan biaya investasi akan kembali atau kapan dana pinjaman untuk pembangunan proyek akan terlunasi. Arus kas merupakan informasi awal bagi perhitungan atau penyusutan studi kelayakan suatu proyek. Informasi yang disusun pada arus kas dapat dibuat secara rinci ataupun cukup garis besarnya saja sesuai dengan analisis ekonomi dalam pembuatan arus kas pada penelitian sebelumnya (Ahmad Antono, A, 2007), seperti pada Tabel 1. 
Tabel 1. Contoh Arus Kas

\begin{tabular}{|l|c|c|c|c|c|}
\hline Keterangan & Tahun ke-1 & Tahun ke-2 & Tahun ke-3 & $\ldots \ldots \ldots$ & Tahun ke-n \\
\hline Kas masuk & & & & & \\
\hline Dana pinjaman & $\mathrm{V}$ & - & - & - & - \\
\hline Penjualan & & $\mathrm{V}$ & $\mathrm{V}$ & $\mathrm{V}$ & $\mathrm{V}$ \\
\hline Jumlah kas masuk & $\mathrm{V}$ & $\mathrm{V}$ & $\mathrm{V}$ & $\mathrm{V}$ & $\mathrm{V}$ \\
\hline Kas keluar & & & & & \\
\hline Biaya investasi & $\mathrm{V}$ & & & & \\
\hline Biaya operasional & & $\mathrm{V}$ & $\mathrm{V}$ & $\mathrm{V}$ & $\mathrm{V}$ \\
\hline Biaya perawatan & & $\mathrm{V}$ & $\mathrm{V}$ & $\mathrm{V}$ & $\mathrm{V}$ \\
\hline Jumlah kas keluar & $\mathrm{V}$ & $\mathrm{V}$ & $\mathrm{V}$ & $\mathrm{V}$ & $\mathrm{V}$ \\
\hline
\end{tabular}

\section{Kriteria Kelayakan Secara Ekonomi}

Beberapa parameter yang dapat digunakan sebagai kriteria kelayakan proyek secara ekonomi antara lain:

\section{a. B/C (Benefit-cost ratio)}

Perhitungan nilai $\mathrm{B} / \mathrm{C}$ dengan persamaan sebagai berikut :

$$
\mathrm{D} / \mathrm{C}=\frac{\sum\left[\frac{\mathrm{E}_{\mathrm{t}}}{(1+\mathrm{r}) t}\right]}{\sum\left[\frac{\mathrm{C}_{\mathrm{t}}}{(1+\mathrm{r})}\right]}
$$

$B_{t}$ : manfaat / pendapatan pada tahun ke-t (Rp)

$C_{t}$ : biaya yang dikeluarkan pada tahun ke-t (Rp)

$r$ : suku bunga bank yang berlaku pada tahun ke-t (\%)

Sebuah proyek dinyatakan layak dibangun apabila nilai $B / C>1$, proyek ini akan menghasilkan keuntungan finansial. Apabila nilai B/C

$<1$, maka proyek ini tidak dapat menghasilkan keuntungan finansial.

b. NPV (Net present value)

Net present value adalah jumlah manfaat dikurangi dengan jumlah biaya yang dikeluarkan selama periode waktu yang sama. Referensi didapat dari buku Ekonomi Teknik (Waldiyono,MS, 2008). Nilai NPV dapat dihitung dengan persamaan sebagai berikut:

$$
N P V=B_{t}-C_{t}
$$


Apabila NPV >0, maka proyek akan mendatangkan keuntungan secara finansial, tetapi jika NPV $<0$, berarti proyek tidak mendatangkan keuntungan secara finansial.

c. IRR (Internal rate of return)

IRR menunjukkan nilai bunga bank dimana besarnya total cost sama dengan total benefit. Jika tingkat suku bunga sebesar IRR, maka nilai NPV $=0$. Jika tingkat suku bunga $r<I R R$, maka suatu proyek secara ekonomi layak untuk dibangun. Meskipun nilai $r=I R R$, secara ekonomi proyek masih cukup layak untuk dilaksanakan.

\section{HASIL DAN PEMBAHASAN}

Data debit saluran irigasi Minggir di Dusun Klagaran diperoleh dari kantor Cabang Dinas Pekerjaan Umum Wilayah Kabupaten Sleman. Data yang diperoleh merupakan data dari bulan januari tahun 2000 hingga bulan januari tahun 2008 dikarenakan keterbatasan data yang tersedia. Dari data tersebut diperoleh debit minimum sebesar 1.650 liter/detik.

Untuk perancangan pembangkit listrik tenaga mikrohidro di saluran ini ditetapkan debit rancangan sebesar 1.500 liter/detik. Debit ini ditetapkan dalam perencanaan oleh CV.Bangun Cipta Persada atau dalam studi kelayakan PLTMH Minggir. Dengan debit rancangan ini, diharapkan tidak terjadi kekurangan suplai air sehingga daya yang dihasilkan dapat mencapai nilai maksimum.

Dari hasil perhitungan daya yang direncanakan oleh CV.Bangun Cipta Persada didapat nilai daya listrik sebesar 20,638 kW. Dalam studi kelayakan ini, dilakukan analisis ulang. Dari analisis rumah pembangkit yang dilakukan, maka diperoleh nilai beda tinggi muka air dibagian atas (pada bak penenang) 
dengan bagian bawah (pada tailrace/saluran pembuang) untuk mengetahui potensi daya yang dapat dibangkitkan oleh PLTMH Minggir.

Daya listrik yang dihasilkan PLTMH Minggir :

$P=$ Q.H.p.g. $\eta=1,5 \times 2 \times 1000 \times 9,81 \times 80 \%=23544$ watt $=23,54 \mathrm{~kW}$

Perancangan mekanikal dan elektrikal dilakukan oleh CV Cihanjuang Inti Teknik Bandung. Hasil perancangan mekanikal dan elektrikal sebagai berikut:

a. Spesifikasi mekanikal

1) Turbin :Open Flume diameter $300 \mathrm{~mm}$ ( 2 buah )

2) Transmisi : Pulley dan $v$-belt ( Pulley type C )

b. Spesifikasi elektrikal

1) Generator : MISG Motor Induksi $12 \mathrm{~kW}$.

2) Sistem control : Kontrol IGC (Chip IGC $10 \mathrm{~kW}$ ), control synchronizer dan ballast load $12 \mathrm{~kW}$ DC.

\section{Rencana Anggaran Biaya (RAB) PLTMH Minggir}

Hasil dari analisis RAB PLTMH Minggir, dapat ditampilkan Rekapitulasi Rencana Anggaran Biaya PLTMH Minggir sebagai berikut:

\begin{tabular}{|c|l|c|c|c|c|}
\hline \multirow{2}{*}{ No } & \multicolumn{1}{|c|}{ Uraian } & \multirow{2}{*}{ Sat } & \multirow{2}{*}{ Vol } & \multicolumn{1}{c|}{ Harga Satuan } & \multicolumn{1}{c|}{ Jumlah } \\
\cline { 5 - 6 } & & & & \multicolumn{1}{|c|}{$(\mathbf{R p})$} & \multicolumn{1}{c|}{$(\mathbf{R p})$} \\
\hline 1 & Pekerjaan persiapan & Ls & 1 & $7.650 .000,00$ & $7.650 .000,00$ \\
\hline 2 & Pekerjaan tanah dan pasir & Ls & 1 & $2.149 .242,38$ & $2.149 .242,38$ \\
\hline \multirow{2}{*}{3} & $\begin{array}{l}\text { Pekerjaan pasangan \& } \\
\text { plesteran }\end{array}$ & Ls & 1 & $52.505 .800,01$ & $52.505 .800,01$ \\
\hline 4 & Pekerjaan beton & Ls & 1 & $29.346 .733,87$ & $29.346 .733,87$ \\
\hline 5 & Pekerjaan kayu & Ls & 1 & $1.942 .959,78$ & $1.942 .959,78$ \\
\hline 6 & Pekerjaan rangka atap & Ls & 1 & $6.868 .000,00$ & $6.868 .000,00$ \\
\hline 7 & Pekerjaan cat-catan & Ls & 1 & $4.043 .201,49$ & $4.043 .201,49$ \\
\hline 8 & Pekerjaan besi & Ls & 1 & $42.250 .000,00$ & $42.250 .000,00$ \\
\hline 9 & Pekerjaan lantai & Ls & 1 & $1.656 .703,13$ & $1.656 .703,13$ \\
\hline 10 & Pekerjaan lain - lain & Ls & 1 & $2.732 .000,00$ & $2.732 .000,00$ \\
\hline 11 & Pekerjaan mekanikal & Ls & 1 & $111.520 .000,00$ & $111.520 .000,00$ \\
\hline
\end{tabular}




\begin{tabular}{|c|c|c|c|c|c|}
\hline 12 & Pekerjaan elektrikal & Ls & 1 & $48.592 .163,70$ & $48.592 .163,70$ \\
\hline 13 & Operasional lapangan & Ls & 1 & $27.255 .000,00$ & $27.255 .000,00$ \\
\hline 14 & Biaya sosialisasi & Ls & 1 & $9.000 .000,00$ & $9.000 .000,00$ \\
\hline & & & & Jumlah $\mathrm{Rp}$ & $347.511 .804,36$ \\
\hline & & & Jasa & traktor $10 \% \mathrm{Rp}$ & $34.751 .180,00$ \\
\hline & & & umla & pelum pajak Rp & $382.262 .984,36$ \\
\hline & & & & PPN 10\% Rp & $38.226 .298,00$ \\
\hline & & & & Total biaya $\mathrm{Rp}$ & $420.489 .282,36$ \\
\hline & & & & Dibulatkan Rp & $420.489 .000,00$ \\
\hline \multicolumn{6}{|c|}{$\begin{array}{l}\text { Terbilang : Empat Ratus Dua Puluh Juta Empat Ratus Delapan Puluh Sembilan Ribu } \\
\text { Rupiah }\end{array}$} \\
\hline
\end{tabular}

\section{Analisis struktur bangunan air}

Hasil dari analisis ulang terhadap struktur bangunan air dapat dilihat pada tabel perbandingan dibawah ini.

Perbandingan Hasil Analisis Konsultan dengan Hasil Studi Kelayakan PLTMH Minggir

\begin{tabular}{|l|c|c|c|c|c|c|c|c|}
\hline \multirow{2}{*}{$\begin{array}{c}\text { JENIS } \\
\text { BANGUNAN } \\
\text { AIR }\end{array}$} & \multicolumn{4}{|c|}{ Analisis Konsultan } & \multicolumn{4}{c|}{ Analisis Studi Kelayakan } \\
\cline { 2 - 9 } & $\begin{array}{c}\mathbf{( m )} \\
\mathbf{( m )}\end{array}$ & $\begin{array}{c}\mathbf{h} \\
\mathbf{( m )}\end{array}$ & $\begin{array}{c}\text { Kemiringan } \\
\text { saluran (I) }\end{array}$ & $\begin{array}{c}\mathbf{L} \\
\mathbf{( m )}\end{array}$ & $\begin{array}{c}\text { B } \\
(\mathbf{m})\end{array}$ & $\begin{array}{c}\mathbf{h} \\
(\mathbf{m})\end{array}$ & $\begin{array}{c}\text { Kemiringan } \\
\text { saluran (I) }\end{array}$ \\
\hline $\begin{array}{l}\text { Bangunan } \\
\text { penyadap air }\end{array}$ & - & 0,9 & 1,2 & - & - & 0,9 & 1,2 & - \\
\hline $\begin{array}{l}\text { Saluran } \\
\text { pembawa }\end{array}$ & - & 2,2 & 1,40 & 0,0016 & - & 2,2 & 1,40 & 0,0016 \\
\hline $\begin{array}{l}\text { Bak } \\
\text { penenang }\end{array}$ & 5,0 & 2,7 & - & - & 5,0 & 3,0 & - & - \\
\hline $\begin{array}{l}\text { Saluran } \\
\text { pembuangan }\end{array}$ & - & 2,5 & 0,66 & 0,00204 & - & 3,0 & 0,66 & 0,0002 \\
\hline
\end{tabular}

\section{Analisis struktur Power House (Pemodelan struktur 3D dengan program SAP2000 version 11.0.0)}

Pada PLTMH Minggir, pihak konsultan belum pernah melakukan analisis terhadap struktur Power House. Maka dari itu, dalam studi kelayakan ini dilakukan analisis struktur terhadap bangunan Power House dengan pemodelan 3D menggunakan software SAP2000 version 11.0.0. Permodelan 
ini adalah untuk mengetahui apakah struktur mampu menahan beban-beban yang bekerja diatasnya. Hasil analisis struktur Power house menggunakan program SAP2000 dapat dilihat pada Gambar berikut.

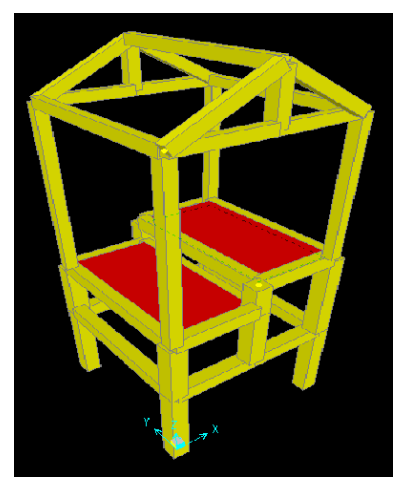

Permodelan rumah pembangkit (Power house)

Momen yang terjadi pada balok dan kolom struktur pada Power House dilihat pada Tabel dibawah ini.

Momen pada Komponen Balok Struktur

\begin{tabular}{|c|r|c|}
\hline Kode Struktur & Momen Maksimum $(\mathrm{kNm})$ & Keterangan \\
\hline B34 (25/30) & 30,786 & \\
\hline B35 $(25 / 30)$ & 36,460 & maksimum 6P16 \\
\hline B38 (25/30) & 2,953 & \\
\hline B39 (25/30) & 2,953 & \\
\hline B40 (20/30) & 3,106 & \\
\hline B41 (20/30) & 3,675 & \\
\hline B44 (20/30) & 33,800 & maksimum 6P12 \\
\hline B45 (20/30) & 27,844 & \\
\hline B47 (20/30) & 11,616 & \\
\hline B48 (15/20) & $-0,497$ & \\
\hline B49 (15/20) & $-0,497$ & \\
\hline B52 (15/20) & 2,961 & maksimum 4P12 \\
\hline B58 (15/20) & 0,779 & \\
\hline B59 (15/20) & 0,779 & \\
\hline B60 (15/20) & 2,560 & \\
\hline
\end{tabular}


Gaya Nominal pada Kolom Struktur

\begin{tabular}{|c|r|r|}
\hline Kode Struktur & Gaya Aksial (kN) & Momen Nominal (kNm) \\
\hline K20 (30/30) & 120,851 & 0,073 \\
\hline K21 (30/30) & 86,217 & 4,926 \\
\hline K18 (30/30) & 147,828 & 2,936 \\
\hline K19 (30/30) & 156,977 & 1,917 \\
\hline K32 (30/30) & 41,455 & 5,674 \\
\hline K33 (30/30) & 13,878 & 13,292 \\
\hline K26 (20/20) & 16,759 & $-2,657$ \\
\hline K27 (20/20) & 16,52 & 2,177 \\
\hline K54 (20/20) & 6,648 & $-4,352 \mathrm{E}-16$ \\
\hline
\end{tabular}

\section{Perhitungan kapasitas dukung struktur}

Dari hasil analisis diperoleh nilai kapasitas dukung struktur balok seperti pada Tabel berikut.

Nilai Kapasitas Dukung Struktur

\begin{tabular}{|c|c|c|c|}
\hline Struktur & Ukuran & Tulangan & $\begin{array}{c}\text { Momen Terfaktor /Mu } \\
(\mathbf{k N m})\end{array}$ \\
\hline Balok & $25 \mathrm{~cm} \times 30 \mathrm{~cm}$ & $6 \mathrm{P} 16$ & 59,756 \\
\hline Balok & $20 \mathrm{~cm} \times 30 \mathrm{~cm}$ & $6 \mathrm{P} 12$ & 43,627 \\
\hline Balok & $15 \mathrm{~cm} \times 20 \mathrm{~cm}$ & $4 \mathrm{P} 12$ & 14,343 \\
\hline
\end{tabular}

\section{Kriteria kelayakan teknis}

Setelah dilakukan analisis data, diperoleh hasil kriteria kelayakan pembangunan PLTMH Minggir secara teknis sebagai berikut :

a. Ketersedian air

Dari data debit pada saluran irigasi Minggir Dusun Klagaran dari bulan Januari 2000 hingga bulan Januari 2008 menunjukkan bahwa debit minimum sebesar 1.650 liter/detik. Untuk debit rancangan ditetapkan sebesar 1.500 liter/detik, dengan debit rancangan yang lebih kecil dari debit minimum, maka kebutuhan air dapat terpenuhi secara kontinyu. 
Pada saat intake saluran Minggir ditutup untuk perbaikan saluran, PLTMH Minggir tidak mendapatkan suplai air sehingga tidak dapat berproduksi. Setiap tahun perbaikan saluran dilakukan selama satu bulan, berarti PLTMH Minggir tidak dapat berproduksi selama satu bulan. Waktu satu bulan dapat dimanfaatkan untuk perbaikan peralatan mekanikal dan elektrikal pada PLTMH.

b. Kemampuan struktur menahan beban

Berdasarkan hasil analisis struktur Power House dengan program SAP2000 dan perhitungan kapasitas dukung struktur, diketahui bahwa rancangan Power House mampu mendukung beban yang terjadi. Hal ini, bisa dibuktikan pada perbandingan nilai kapasitas dukung struktur dengan nilai gaya nominal yang terjadi pada struktur. Perbandingan ini dapat dilihat pada Tabel berikut.

Perbandingan Kapasitas Dukung Struktur dengan Gaya Nominal yang Terjadi pada Struktur

\begin{tabular}{|c|c|c|c|c|c|}
\hline Struktur & Ukuran & Tulangan & $\begin{array}{c}\text { Mu } \\
(\mathbf{k N m})\end{array}$ & $\begin{array}{c}\mathbf{0 , 8} \text { Mu } \\
(\mathbf{k N m})\end{array}$ & $\begin{array}{c}\text { Mu max } \\
(\mathbf{k N m})\end{array}$ \\
\hline Balok & $25 \mathrm{~cm} \times 30 \mathrm{~cm}$ & $6 \mathrm{P} 16$ & 59,756 & 47,805 & 36,460 \\
\hline Balok & $20 \mathrm{~cm} \times 30 \mathrm{~cm}$ & $6 \mathrm{P} 12$ & 43,627 & 34,902 & 33,800 \\
\hline Balok & $15 \mathrm{~cm} \times 20 \mathrm{~cm}$ & $4 \mathrm{P} 12$ & 14,343 & 11,474 & 2,961 \\
\hline
\end{tabular}

Dari tabel diatas menunjukkan bahwa nilai $(0,8 . \mathrm{Mu})$ lebih besar dari $\mathrm{Mu}$ max yang bekerja pada struktur balok Power House, sehingga dimensi struktur balok mampu mendukung gaya yang terjadi. Gambar dibawah ini. menunjukkan gaya pada struktur di diagram interaksi kolom. 


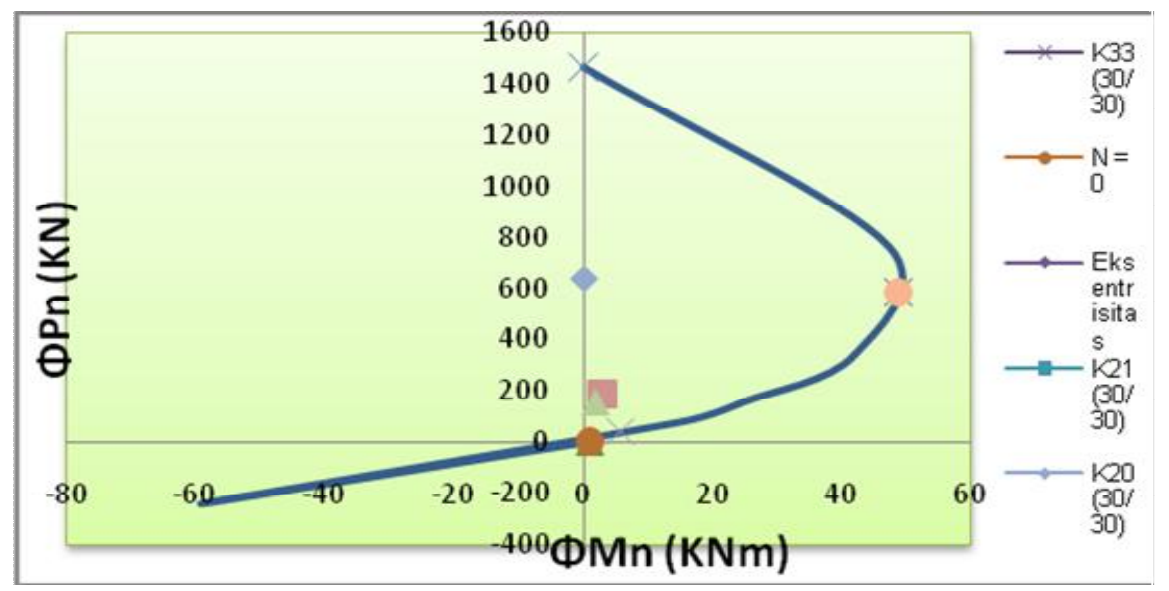

Gaya yang Terjadi pada Kolom Struktur

Dari Gambar diatas dapat dilihat bahwa gaya yang terjadi pada kolom struktur masih berada di dalam diagram interaksi kolom, hal ini menunjukkan bahwa kolom struktur mampu mendukung gaya - gaya yang terjadi.

c. Ketersediaan peralatan mekanikal dan elektrikal di pasaran

Daya yang dapat dibangkitkan oleh PLTMH Minggir sebesar 23,54 kW. CV.Cihanjuang Inti Teknik Bandung adalah merupakan produsen turbin lokal, sehingga semua peralatan mekanikal dan elektrikal pada PLTMH Minggir dapat diperoleh di pasaran.

Dari hasil analisis yang telah dilakukan, pembangunan pembangkit listrik tenaga mikrohidro di Dusun Klagaran, Desa Sendangrejo, Kecamatan Minggir, Kabupaten Sleman secara teknis layak untuk dibangun.

\section{Analisis Ekonomi}

Dari analisis ekonomi yang dilakukan dengan tiga alternatif sumber dana untuk pembangunan PLTMH Minggir, maka diperoleh nilai masingmasing parameter seperti yang tercantum pada tabel berikut ini : 
Analisis Ekonomi PLTMH Minggir

\begin{tabular}{|c|l|c|c|c|}
\hline No & \multicolumn{1}{|c|}{ Parameter } & I (Rp) & II (Rp) & III (Rp) \\
\hline 1 & Total biaya investasi & 580.274 .000 & 504.586 .000 & 504.586 .000 \\
\hline 2 & Bunga bank per tahun & $18 \%$ & - & - \\
\hline 3 & Biaya tahunan & 121.857 .000 & 15.137 .000 & 15.137 .000 \\
\hline 4 & $\begin{array}{l}\text { Waktu pelunasan } \\
\text { pinjaman (tahun) }\end{array}$ & - & 22 & - \\
\hline 5 & $\begin{array}{l}\text { Manfaat/pendapatan } \\
\text { tahunan }\end{array}$ & 44.744 .000 & 44.744 .000 & 44.744 .000 \\
\hline 6 & BCR & 0,20 & 0,63 & 2,96 \\
\hline 7 & NPV = (B-C) & -847.977 .000 & -216.886 .000 & 241.829 .000 \\
\hline 8 & IRR & - & $13 \%$ & - \\
\hline
\end{tabular}

Keterangan :

I : Sumber dana dari pinjaman bank

II : Sumber dana dari pinjaman tanpa bunga pemerintah atau donor

III : Sumber dana dari hibah pemerintah atau donor.

\section{KESIMPULAN}

1. Potensi daya yang dibangkitkan dari PLTMH Minggir adalah sebesar 23,54 kilowatt.

2. Pembangunan PLTMH Minggir memenuhi kriteria kelayakan secara teknis.

3. Secara finansial, pembangunan PLTMH Minggir tidak dapat mendatangkan keuntungan jika dibiayai dengan pinjaman bank dengan bunga 18\% per tahun. Bunga maksimum yang dapat ditanggung oleh pengelola bila mengharapkan kondisi impas tiap tahunnya sebesar kurang lebih 0,4\% per tahun selama 22 tahun.

4. Pembangunan PLTMH akan mendatangkan keuntungan secara finansial, jika dibiayai dengan pinjaman tanpa bunga atau hibah dari pemerintah ataupun dari pihak donor. 


\section{SARAN}

1. Pemerintah diharapkan turut andil dalam memberikan subsidi untuk pembangunan PLTMH Minggir agar layak untuk dikerjakan.

2. Perlu diadakan kajian tentang daya beli masyarakat, terutama yang belum mendapatkan aliran listrik dari PT PLN. Hal ini bertujuan untuk mengetahui kemungkinan meningkatkan harga jual daya listrik yang dihasilkan PLTMH Minggir.

\section{DAFTAR PUSTAKA}

Ahmad Antono, A. 2007. Studi Kelayakan Pembangkit Listrik Tenaga Mikrohidro studi kasus: PLTMH Kalibawang di Dusun Sorotanan Desa Banjararum Kecamatan Kalibawang Kabupaten Kulonprogo. Tugas Akhir tidak diterbitkan. Yogyakarta: Universitas Gadjah Mada.

Anonim. 1987. Pedoman Perencanaan Pembebanan untuk Rumah dan Gedung. Yayasan Penerbit PU.

Anonim. 2002. Standar Perencanaan Ketahanan Gempa untuk Struktur Bangunan Gedung SNI-1726-2002. Jakarta: Departemen Kimpraswil.

Anonim. 2002. Tata Cara Perhitungan Struktur Beton untuk Bangunan Gedung SK SNI 03-2847-2002. Jakarta: Badan Standarisasi Nasional.

Chow, V.T. 1989. Hidraulika Saluran Terbuka. Jakarta: Penerbit Erlangga.

Karmolis. 2005. Pembangkit Listrik Tenaga Air: Materi Kursus Singkat. Yogyakarta: Magister Sistem Teknik Sekolah Pascasarjana Universitas Gadjah Mada.

Meier, T. 1995. Tenaga Air. Surabaya: Erlangga.

Patty, O.F. 1995. Tenaga Air. Surabaya: Erlangga.

Waldiyono, MS. 2008. Ekonomi Teknik: Konsepsi, Teori dan Aplikasi. Yogyakarta: Pustaka Pelajar.

Yulistiyanto, B. 2001. Hidraulika Sungai: Suatu Pengantar Praktis. Yogyakarta: JTS-FT UGM. 